DOI

\title{
ДЕЯКІ ПРОБЛЕМИ ВИКЛАДАННЯ ДИСЦИПЛІНИ “ЗАГАЛЬНА ПРАКТИКА - СІМЕЙНА МЕДИЦИНА” СТУДЕНТАМ VІ КУРСУ МІЖНАРОДНОГО ФАКУЛЬТЕТУ АНГЛІЙСЬКОЮ МОВОЮ
}

\author{
Г. В. Грицай
}

Запорізький державний медичний університет

\section{SOME PROBLEMS OF TEACHING OF GENERAL PRACTICE - FAMILY MEDICINE IN ENGLISH TO FOREIGN STUDENTS}

H. V. Hrytsay

\author{
Zaporizhian State Medical University
}

\begin{abstract}
Стаття розглядає методичні особливості та проблеми викладання дисципліни “Загальна практика - сімейна медицина” студентам VI курсу міжнародного факультету англійською мовою. На підставі досвіду викладання наведені заходи щодо вирішення цих проблем: активізація роботи по створенню навчально-методичних посібників англійською мовою, що містять теоретичний матеріал, відповідно до навчальної програми, оновлення та удосконалення бази тестових завдань і ситуаційних задач клінічної спрямованості, створення практикуму для практичних занять.
\end{abstract}

The article considers the certain methodical peculiarities and specific questions of teaching general practice - family medicine to English-speaking students. On the basis of experience the pathways of solving these problems are suggested to be. Using the combination of writing text with scheme, figure and presentation lead to better studying of material and solving situational tasks. Some difficulties arose because of perception of teacher's speech by students. During examination of patients they needed of teacher's translation. We offer next measures for solving these problems: active creation of study manuals on English language, with theoretical material according to working program, update and improve tests and situational tasks database, creation of notebook for practical lessons.

Вступ. Загальна практика - сімейна медицина - важлива навчальна дисципліна у підготовці студента-медика. Вона базується на вивченні внутрішньої медицини, хірургії, інфекційних хвороб, епідеміології, педіатрії, ендокринології, неврології, онкології, офтальмології, дерматології, клінічної імунології, отоларингології й фармакологї̈, реаніматології, соціальної медицини та охорони здоров’я, гігієни та екології, біостатистики, інформатики, етики та деонтології, морфологічних дисциплін й інтегрується з ними [4, 5]. Сімейна медицина широко розповсюджена в країнах Європи i займає центральне місце в наданні допомоги населенню, як найбільш раціональної з точки зору економного застосування ресурсів охорони здоров'я та ефективного масового обслуговування населення [1, 2, 6].

В останній час у Запорізькому державному медичному університеті спостерігається збільшення кількості іноземних студентів, що отримують медичну освіту англійською мовою. Тому в цій статті наведено наш досвід викладання навчальної

(C) Г. В. Грицай дисципліни “Загальна практика - сімейна медицина” студентам VI курсу міжнародного факультету, що навчаються зі спеціальності “Лікувальна справа” англійською мовою.

Основна частина. Основні цілі та завдання викладання дисципліни “Загальна практика - сімейна медицина”, відповідно до вимог освітньопрофесійної програми підготовки, спрямовані на засвоєння теоретичних знань основ організації первинної медико-санітарної допомоги на засадах лікаря загальної практики: напрямки та форми організації роботи, функціональні обов'язки сімейного лікаря, види лікувально-діагностичної та профілактичної діяльності [4].

Студент повинен знати та вміти проводити раннє виявлення хворих із найбільш поширеною патологією внутрішніх органів, призначати комплекс діагностичних досліджень та лікувально-профілактичних заходів, визначати показання до стаціонарного лікування, реалізовувати диспансерний метод, санітарно-протиепідемічні заходи та комплексні плани оздоровлення населення $[4,5]$.

Видами навчальної активності студентів є практичні заняття та самостійна робота. Практичні 
заняття проводяться на клінічних базах кафедри загальної практики - сімейної медицини в КЗ “Центр первинної медично-санітарної допомоги № 6” та в стаціонарі К3 “Центральна лікарня № 4 Заводського району”. Особлива увага при розборі теоретичного матеріалу приділяється питанням місця сімейної медицини в загальній структурі охорони здоров’я та принципам сімейного обслуговування населення, організації роботи сімейного лікаря, основній обліковій медичній документації в закладах сімейної медицини, медико-соціальним аспектам здоров’я населення, діяльності сімейного лікаря в умовах страхової медицини, диспансеризації, реабілітації, організації долікарської допомоги при найбільш поширених захворюваннях терапевтичного профілю, загальним питанням медикосоціальної експертизи, організації роботи денних і домашних стаціонарів [4].

Згідно з навчальною програмою, на вивчення дисципліни “Загальна практика - сімейна медицина” відводиться 50 годин практичних занять та 40 годин самостійної роботи [4]. Цієї схеми ми й дотримувались при проведенні занять з англомовними студентами.

Практичне заняття з дисципліни “Загальна практика - сімейна медицина” складається з декількох частин. По-перше, разом із викладачем розглядаються теоретичні питання, проводиться вхідний контроль знань студентів, потім студентам пропонується практичне застосування знань у вигляді вирішення ситуаційних задач.

Мала місце необхідність адаптації вимог вітчизняної програми та особливостей викладання дисципліни в закордонних країнах, розбіжності в програмах ведення амбулаторних пацієнтів терапевтичного профілю з застосуванням трьохетапності надання медичної допомоги, проведенні диспансеризації здорових і хворих, оформленні медичної документації.

При підготовці курсу практичних занять перед нами виникла проблема відсутності навчальних матеріалів англійською мовою. В першу чергу це стосувалося методичних вказівок до проведення практичних занять. Тому нашим першим завданням були їх адаптація та переклад на англійську мову.

В наших методичних вказівках та посібниках до проведення практичного заняття для студентів наводяться тема заняття, його актуальність, навчальні цілі, перелік питань до самостійної теоретичної підготовки, практичних навичок та необхідних теоретичних матеріалів.
Ефективність викладання загальної практики сімейної медицини іноземним студентам 6-го року навчання англійською мовою обумовлена відсутністю мовного бар’єра між викладачем та студентом, застосуванням професійної термінології на англійській мові, застосуванням різних наочних посібників [2].

Однак наш досвід викладання іноземним студентам свідчить про наявність деяких методичних особливостей, пов’язаних із викладанням англійською мовою та контингентом студентів.

У ході вивчення дисципліни, при застосуванні підготовлених на кафедрі навчально-методичних матеріалів, було відмічено краще розуміння та більш глибоке осмислення навчального матеріалу у вигляді написаного тексту, який суміщений 3 малюнками і схемами презентацій. Це відносилося й до вирішення ситуаційних задач на практичних заняттях.

У ряді випадків деякі труднощі виникали у сприйнятті мови викладача студентами-іноземцями, головним чином, громадянами Індії, оскільки поза навчальним закладом вони частіше спілкуються на хінді, а англійську мову застосовують переважно для читання підручників та методичних посібників.

Крім того, під час спілкування з хворими студенти не мають можливості говорити з ними російською мовою, що потребує участі викладача в процесі курації хворого. Опитування, клінічний огляд хворих, аналіз медичної документації потребують перекладу з боку викладача.

3 метою перевірки поточного та підсумкового контролю рівня знань англомовних студентів співробітниками кафедри створена база тестових завдань англійською мовою. Поточний контроль у вигляді тестових завдань до теми проводиться наприкінці кожного практичного заняття. Результати тестування є складовою частиною оцінки знань студента.

Самостійна робота студентів забезпечена всіма навчально-методичними матеріалами: методичними розробками, мультимедійними презентаціями, посібниками, ситуаційними завданнями, збірниками тестових завдань.

Перевірка знань студентів реалізується у кінці циклу на підсумковому занятті завідувачем кафедри у вигляді співбесіди з ними. Крім того, кожний студент отримує 4 ситуаційні задачі, в результаті вирішення яких він має сформулювати клінічний діагноз, запропонувати план обстеження пацієнта, 
призначити лікування, визначити методи первинної та вторинної профілактики. Підсумковий тестовий контроль включає тестові завдання, що охоплюють всі розділи циклу.

Висновок. Таким чином, підвищити ефективність викладання дисципліни “Загальна практика сімейна медицина” англомовним студентам дозволить активізація роботи по створенню навчально-

\section{Список літератури}

1. Вища медична освіта України на сучасному етапі / В. В. Лазоришинець, М. В. Банчук, О. П. Волосовець [та співавт.] // Проблеми сучасної медичної науки та освіти. 2008. - № 2. - C. 5-10.

2. Лехан В. М. Стратегія розвитку системи охорони здоров’я : Укр. вимір / В. М. Лехан, Г. О. Слабкий, М. В. Шевченко. - К., 2009. - С. 3.

3. Мілерян В. Є. Методичні основи підготовки та проведення навчальних занять в медичних вузах (методичний посібник) / В. Є. Мілерян. - К., 2004. - 80 с.

4. Робоча програма з дисципліни “Загальна практика сімейна медицина” підготовки спеціаліста напряму 1201 “Медицина” спеціальність 7.12010001 “Лікувальна справа”, 7.12010002 “Педіатрія”. - Запоріжжя, 2014. - 27 с. методичних посібників англійською мовою, зміст яких охоплює весь теоретичний матеріал, передбачений навчальною програмою, оновлення та вдосконалення бази тестових завдань та ситуаційних задач клінічної спрямованості, створення та щоденне застосування практикуму для практичних занять для закріплення знань студентів.

5. Становлення нової моделі надання первинної медико-санітарної допомоги на засадах сімейної медицини в Україні - не данина моді, а об’єктивна реальність / Л. Ф. Матюха, Н. Г. Гойда, В. А. Одринський [та співавт.] // Сімейна медицина. - 2013. - № 4. С. $157-158$.

6. Доцільність реформування амбулаторно-поліклінічної системи та переходу до практики сімейного обслуговування населення / О. М. Гиріна, В. О. Сірик, Н. М. Горобець, Т. І. Калюжна // Сімейна медицина. 2010. - № 3. - C.10-15.

Отримано 29.09.15 